\title{
EVALUASI FASILITAS HALTE DAN PENENTUAN KEBUTUHAN HALTE DI KOTA TEGAL
}

\author{
Pipit Rusmandani ${ }^{1}$, Riandy Sholeh Setiawan'2, Yan El Rizal Unzilatirrizqi D ${ }^{3}$ \\ Program Studi Manajemen Keselamatan Transportasi Jalan \\ Politeknik Keselamatan Transportasi Jalan \\ Jalan Semeru No.3 Kota Tegal, Jawa Tengah 52125 \\ E-mail: pipit@pktj.ac.id
}

\begin{abstract}
Abstrak
Tempat perhentian angkutan atau halte atau shelter adalah tempat untuk menaikkan dan menurunkan penumpang, biasanya ditempatkan pada jaringan pelayanan angkutan. Penelitian tantang halte telah dilakukan oleh beberapa peneliti sebelumnya baik dilihat dari sis teknis maupun dari sisi persepsi pengguna. Karena pada dasarnaya penyediaan halte ini selain keandalan dan kinerja, salah satu faktor yang dapat mempengaruhi minat masyarakat untuk menggunakan angkutan umum adalah kenyamanan dan estetikadari fasilitas pendukungnya. Penelitian ini bertujuan untuk mengevaluasi fasilitas halte dan keberaan halte serta menentukan kebutuhan halte baik dari sisi teknis aksesibilitas maupun persepsi masyarakat. Penelitian ini menghasilkan kesimpulan Kebutuhan penyediaan halte mengedepankan pelayanan dari angkutan umum itu sendiri dan kebutuhan dari masyarakat baik dari tata letaknya maupun desain halte agar tercapai pelayanan yang optimal serta dapat menguruangi penggunaan angkutan pribadi dan meningkatkan penggunaan angkutan umum. Dari 27 halte eksisting terdapat 4 unit halte harus dibongkar/pindah, sedangkan 23 unit masih dapat melayani pelayanan angkutan. Berdasarkan hasil analisis kebutuhan diperoleh kebutuhan halte tambahan sebanyak 24 unit.
\end{abstract}

Kata kunci: Tempat Perhentian Bus, shelter

\section{PENDAHULUAN}

Karakter umum transportasi publik melayani masyarakat dengan mobilitas dan akses pada pekerjaan, sumber-sumber sosial ekonomi politik, pusat kesehatan, dan tempat rekreasi. Apapun motivasi masyarakat, baik yang sadar dan memutuskan untuk memilih transportasi umum ataupun yang terpaksa karena tidak memiliki pilihan lain, ada kecenderungan penumpang transportasi umum tidak memiliki mobil dan harus bergantung pada transportasi umum, (Aminah, 2018). Selain keandalan dan kinerja, salah satu faktor yang dapat mempengaruhi minat masyarakat untuk menggunakan angkutan umum adalah kenyamanan dan estetika. Menurut penelitian terdahulu bahwa Faktor yang paling mempengaruhi intensi dalam menggunakan TransJakarta adalah faktor kebersihan lingkungan serta adanya gangguan, seperti keramaian dan penerangan pada jalur pejalan kaki, (Farizi, 2016). Pemilihan terhadap penggunaan angkutan umum ini tidak sebanding dengan pelayanan yang diberikan yang bermula dari tempat perhentian angktuan umum atau yang sering kita kenal dengan sebutan halte. Hal in juga dapat berpengaruh terhadap minat orang menggunakan angkutan umum dimuli dari letak halte yang 
jauh dari pusat keramian atau tempat tujuan untuk menunggu atau turun dari angkutan umum, fasilitas halte yang tidak memadai, tidak tersedia papan trayek sampai gangguan menunggu dihalte karena adanya pedagang kaki lima.

Tempat perhentian angkutan atau halte atau shelter adalah tempat untuk menaikkan dan menurunkan penumpang, biasanya ditempatkan pada jaringan pelayanan angkutan. Semakin banyak penumpang yang naik turun di suatu tempat perhentian semakin besar dan semakin lengkap fasilitas yang disediakan. Untuk tempat perhentian yang kecil cukup dilengkapi dengan rambu lalu lintas saja, dan untuk perhentian yang besar bisa dilengkapi dengan atap dan tempat duduk.

Berdasarkan Pedoman Teknis Perekayasaan Tempat Perhentian Kendaraan Penumpang Umum yang dikeluarkan oleh Direktur Jenderal Perhubungan Darat tahun 1996, perekayasaan tempat perhentian kendaraan umum adalah teknikteknik perencanaan tempat perhentian kendaraan penumpang umum yang disediakan bagi pengguna angkutan umum untuk naik/turun atau melakukan perpindahan moda angkutan umum dengan selamat, tertib, lancar, aman, dan nyaman. Tujuan perekayasaan tempat perhentian kendaraan penumpang umum (TPKPU) yaitu menjamin kelancaran dan ketertiban arus lalu lintas, menjamin keselamatan bagi pengguna angkutan penumpang umum, menjamin kepastian keselamatan untuk menaikkan dan/atau menurunkan penumpang, memudahkan penumpang dalam melakukan perpindahan moda angkutan umum atau bus.

Penelitian ini bertujuan untuk mengevaluasi fasilitas halte dan keberaan halte serta menentukan kebutuhan halte baik dari sisi teknis aksesibilitas maupun persepsi masyarakat . Kota Tegal sampai dengan akhir tahun 2019 terdapat 1 celukan halte dan 27 Halte. Berdasarkan kondisi dan perkembangan global dan perubahan pola pada masyarakat (disruption) yang cenderung beralih dari era kendaraan pribadi dan era modern 4.0 yang membuat angkutan daring menjadi primadona tentunya sebagai pemerintah tidak bisa menutup mata karena perubahan tersebut juga akan menimbulkan efek-efek yang negatif terutama terhadap pelayanan transportasi di Kota Tegal Berdasarkan hal tersebut Pemerintah dalam hal ini Pemerintah Kota Tegal pada khususnya harus dapat ambil bagian dalam upaya untuk merespon perubahan yang terjadi secara drastis di masyarakat terutama dalam peningkatan pelayanan publik di bidang angkutan umum.

Persyaratan umum tempat perhentian kendaraan penumpang umum berdasarkan pedoaman tenis perekayasaan tempat perhentian kendaraan penumpang umum, (Perhubungan, 1996) yaitu :

a. berada di sepanjang rute angkutan umum/bus;

b. terletak pada jalur pejalan (kaki) dan dekat dengan fasilitas pejalan (kaki);

c. diarahkan dekat dengan pusat kegiatan atau permukiman;

d. dilengkapi dengan rambu petunjuk;

e. tidak mengganggu kelancaran arus lalu-lintas.

Fasilitas Tempat Pemberhentian Kendaraan Penumpang Umum (TPKPU) Fasilitas utama Halte yaitu :

a. identitas halte berupa nama dan/ atau nomor

b. rambu petunjuk

c. papan informasi trayek

d. lampu penerangan

e. tempat duduk 
Fasilitas Tempat Pemberhentian Kendaraan Penumpang Umum (TPKPU) Fasilitas utama

Tempat Perhentian Bus (TPB) yaitu :

a. rambu petunjuk

b. papan informasi trayek

c. identifikasi TPB berupa nama dan/atau nomor

Fasilitas tambahan :

a. telepon umum

b. tempat sampah

c. pagar

d. papan iklan/pengumuman

Pada persimpangan, penempatan fasilitas tambahan itu tidak boleh mengganggu ruang bebas pandang.

Berdasarkan Pedoman Perencanaan teknis fasilitas pejalan kaki, (Kementrian Pekerjaan Umum dan Perumahan Rakyat, 2018) Keberadaan pemberhentian sementara atau halte tidak boleh mengurangi lebar efektif trotoar. Halte dapat ditempatkan di depan ataupun belakang lajur pejalan kaki. Seperti pada gambar 2.1 berikut ini :

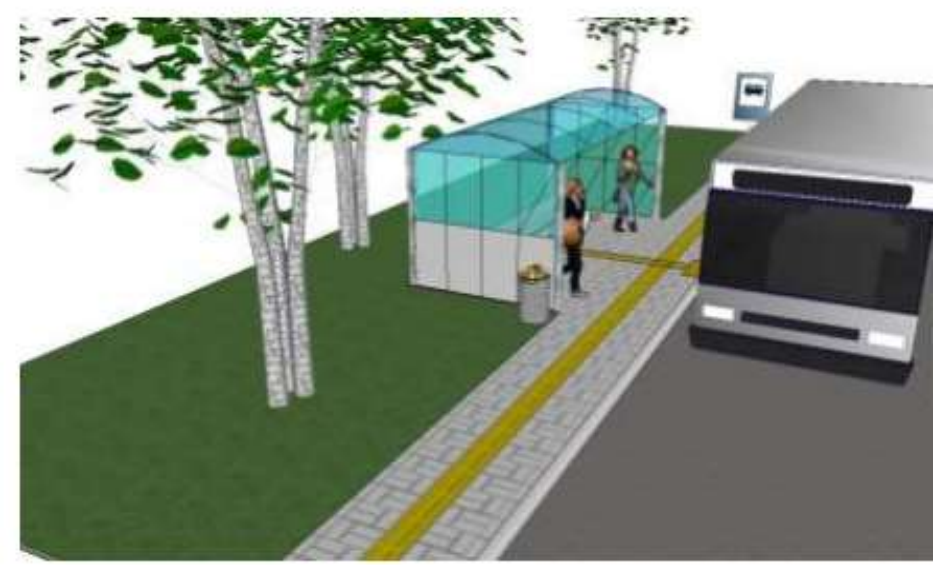

Gambar 1. Contoh halte yang terletak di belakang jalur pejalan kaki

\section{METODE PENELITIAN}

Kajian ini diolah dengan menggunakan metode penelitian kuantitatif yang bersifat advocacy/parcipatory (Creswell, 2008) untuk mengetahui solusi permasalahan secara pragmatis dan combined-strategies (Groat \& Wang, 2002) dengan harapan mengetahui pandangan masyarakat tentang kondisi angkutan umum untuk melakukan perubahan terhadap fasilitas transportasi umum lebih baik.

Metodologi dalam studi ini dibangun berdasarkan dua pendekatan, yaitu : Pendekatan Sistem Aktivitas dan Pendekatan Kebijakan Pemerintah. Secara garis besar, pelaksanaan studi meliputi beberapa bagian :

a. Melakukan pengamatan terhadap halte yang berada di Kota Tegal;

b. Melakukan survei primer dan sekunder guna mengidentifikasi karakteristik halte yang didasarkan atas kuisioner dan inventarisasi

c. Membandingkan kebijakan yang dikeluarkan oleh pemerintah mengenai penyediaan halte dengan karakteristik keberadaan halte yang di lapangan. 
Evaluasi halte dilakukan dengan analisis halte yang ada di Kota Tegal. Evaluasi secara umum dilakukan dengan kombinasi metode observasi, pengukuran, dan komparasi digunakan dalam metode analisis. Observasi dan pengukuran dilakukan untuk menilai dan mengamati kondisi fisik halte yang sudah ada, selanjutnya hasil yang ada dibandingkan dengan

persyaratan teknis yang ada pada Pedoman Teknis Perekayasaan Tempat Perhentian Kendaraan Penumpang Umum yang dikeluarkan oleh Direktur Jenderal Perhubungan Darat tahun 1996.

\section{HASIL DAN PEMBAHASAN}

Panggunaan moda angkutan umum saat ini yang sudah mulai berkurang hal ini juga mengakibatkan fungsi dari halte yang juga berubah diantaranya dipergunakan sebagai tempat berjualan oleh pedagang kaki lima. Perubahan fungsi halte ini perlu dilihat dari hasil identifikasi dan evaluasi halte serta intensitas penggunaan oleh calon penumpang angkutan umum yang pada penelitian ini dapat terlihat dari persepsi masyarakat tentang penggunaan angkutan umum dan penggunaan halte.

\section{Identifikasi dan Evaluasi Halte}

Gambaran lokasi halte yang ada di kota tegal dapat terlihat dari gambar 4.1 berikut ini :

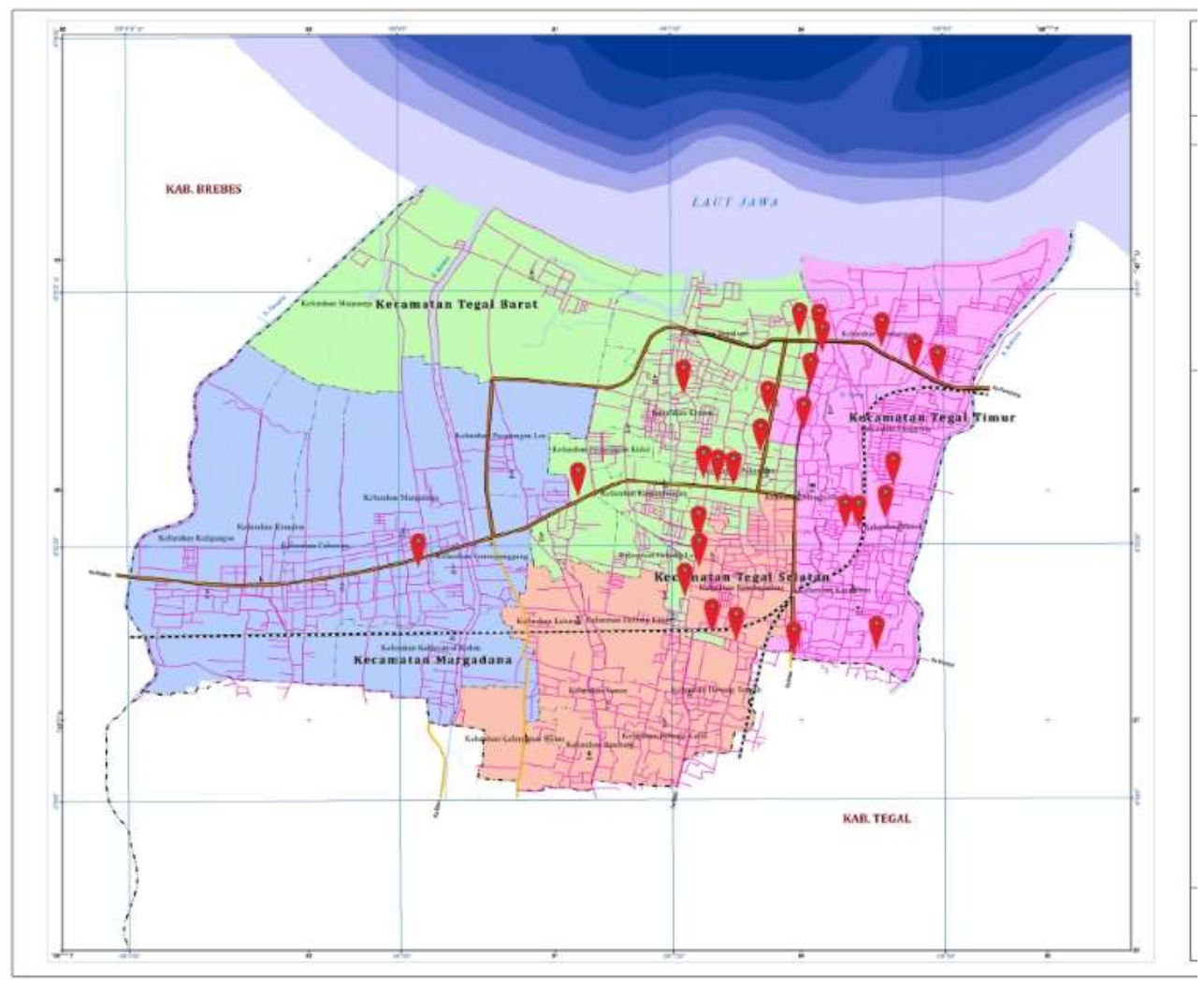

Gambar 2. Letak Halte Eksisting

Kota Tegal sampai dengan akhir tahun 2019 terdapat 1 celukan halte dan 27 Halte. Pada tabel 1.1 berikut disajikan tabel inventarisasi kondisi Halte di Kota Tegal. 
Tabel 1. inventarisasi kondisi Halte di Kota Tegal

\begin{tabular}{|c|c|c|c|c|c|c|c|c|c|c|c|c|c|c|}
\hline \multirow[b]{2}{*}{10} & \multirow[b]{2}{*}{ М⿻анакіL } & \multicolumn{6}{|c|}{ FASIIIISOUTAMU } & \multicolumn{6}{|c|}{ 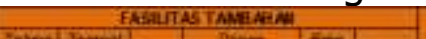 } & \multirow[b]{2}{*}{ кетЕекต } \\
\hline & & Fat & tens & Anetiv & $\operatorname{Lamin} 2$ & 20 & $F=$ & 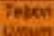 & 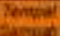 & | I & pers & $F$ & A thp & \\
\hline & & 4 & 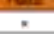 & 4 & $x$ & 4 & 4 & $=$ & &. & 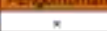 & 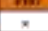 & $\times$ & 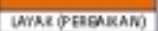 \\
\hline & HALTE YOS SLOFRSOI & $\frac{4}{4}$ & . & & $*$ & 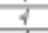 & $\frac{4}{4}$ &. & 4 & 4 & * & $x$ & 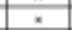 & 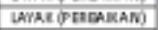 \\
\hline & HQLTE GAMGIMOAA & $\frac{1}{4}$ & 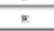 & $\frac{1}{4}$ & $x$ & 1 & 4 & $\pi$ & $x$ & $\pi$ & $x$ & $x$ & $x$ & \\
\hline & 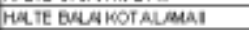 & 4 & $\%$ & 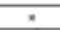 & $x$ & 1 & 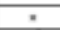 & 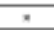 & 9 & 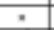 & 7 & $x$ & $\pi$ & DSEDERAARAKAN \\
\hline & HA4 IF SMRN 3 & $\frac{1}{7}$ & $\cdot$ & 1 & $\dot{\nabla}$ & 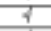 & 4 & 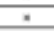 & $\div$ & 2 & 7 & 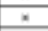 & $*$ & LATRS PEEBBAKAM) \\
\hline & HA.TE SMA 1 & $\frac{1}{2}$ & 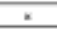 & $x$ & 9 & 1 & $\frac{1}{2}$ & 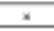 & 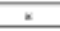 & $\frac{1}{4}$ & $\frac{1}{4}$ & $x$ & $x$ & LATRS P PEBGAKAN \\
\hline & HALTE SMPN 2 & $\sqrt{2}$ & $x$ & $\bar{x}$ & $x$ & 7 & $\bar{x}$ & $x$ & $x$ & $x$ & & $x$ & $x$ & UTRE PFEBSAKAM \\
\hline & HALTE SNEN1 1 & $\frac{1}{2}$ & $x$ & $x$ & $x$ & 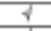 & $x$ & $x$ & $\frac{1}{2}$ & $x$ & 1 & $x$ & $x$ & GTRR PFESARAM \\
\hline & HQLTE A YANA & $\frac{1}{4}$ & $x$ & $x$ & $\times$ & 7 & $\pi$ & $x$ & 8 & $x$ & $x$ & $x$ & $x$ & 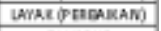 \\
\hline & HQLTE DQLAKOTALAMAI & $\frac{1}{9}$ & 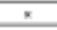 & $x$ & 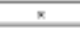 & 1 & 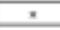 & $x$ & 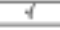 & 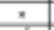 & 7 & $x$ & $x$ & Dineous \\
\hline & HQLTE NAROAOANA & $\frac{1}{4}$ & $*$ & $*$ & $*$ & 1 & $\cdot$ & 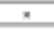 & $*$ & $\frac{1}{1}$ & 1 & 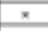 & 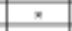 & WHRE PFESAKAM) \\
\hline & HALTE NAY.EN SUTOYOI & 4 & 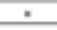 & $\sqrt{2}$ & $*$ & 1 & $\cdot$ & . & 4 & 4 & 7 & 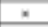 & 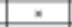 & ahays \\
\hline & HQLTE KAPTEN SLOBVOI & 1 & 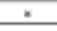 & 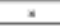 & $x$ & 1 & $\therefore$ & 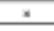 & 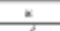 & $\dot{\square}$ & $\frac{1}{1}$ & $x$ & $x$ & 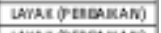 \\
\hline & HALIE SMPN7 & $\frac{1}{1}$ & $x$ & $x$ & 1 & 8 & $\therefore$ & $x$ & 1 & 1 & 7 & $x$ & $x$ & LATRE (Y)EBBAKAN) \\
\hline & HA.TE KAPTEN SLOBVO I & $\frac{1}{4}$ & 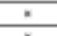 & $\dot{\square}$ & 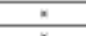 & 7 & $\dot{\square}$ & $\dot{*}$ & 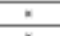 & $\dot{5}$ & 7 & $\dot{x}$ & $\bar{*}$ & 90es9 \\
\hline & HA.TE IENDRA SUTOYOI & $\frac{1}{8}$ & $\therefore$ & $\dot{1}$ & $x$ & $\frac{1}{4}$ & $\therefore$ & $\therefore$ & $x$ & $\frac{1}{8}$ & $\frac{7}{8}$ & $x$ & $x$ & 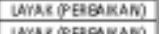 \\
\hline & 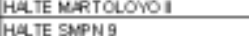 & $\frac{y}{y}$ & $\frac{x}{x}$ & $\frac{\gamma}{\gamma}$ & $\frac{9}{x}$ & $\frac{1}{4}$ & $\dot{x}$ & $x$ & $\frac{1}{x}$ & $x^{2}$ & $\frac{1}{8}$ & $\frac{x}{x}$ & $\frac{x}{x}$ & 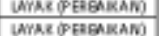 \\
\hline & HELTE SMAT3 3 & $\frac{1}{1}$ & $x$ & $x$ & $\frac{1}{1}$ & 4 & $\mathrm{~s}$ & $x$ & 8 & $\sqrt{7}$ & 4 & $\frac{x}{x}$ & $\frac{1}{x}$ & 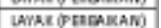 \\
\hline & HELTE POLTREN & $\frac{1}{4}$ & * & $\frac{1}{4}$ & $\frac{1}{4}$ & 1 & 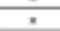 & $x$ & 8 & 4 & 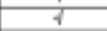 & $\frac{\hat{x}}{x}$ & $\frac{1}{x}$ & 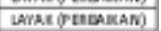 \\
\hline 24 & HaL TE SUTMNACUNG & 4 & . & . & 4 & $\frac{1}{1}$ & 7 & , & 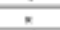 & 4 & 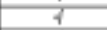 & $x$ & x & 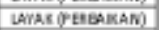 \\
\hline & 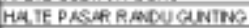 & 1 & $\cdot$ & . & 9 & 1 & $\frac{1}{4}$ & . & 9 & $\frac{4}{4}$ & $\frac{1}{4}$ & $x$ & 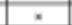 & 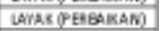 \\
\hline & HALTE NARTOLOYOI & $\frac{1}{4}$ & 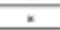 & $\frac{1}{4}$ & 9 & $\frac{1}{4}$ & 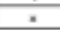 & 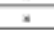 & $\frac{1}{4}$ & $\frac{1}{4}$ & 7 & $x$ & $x$ & 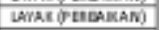 \\
\hline & HALTE PEOADH米 & $\dot{*}$ & $x$ & $x$ & $\mathrm{x}$ & 8 & $\bar{x}$ & $x$ & $\bar{x}$ & 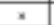 & $\bar{x}$ & $x$ & 7 & DHAPLS \\
\hline & HALTE SMP MUHAMAONYOH & 7 & $x$ & 1 & 1 & 8 & 1 & $x$ & 1 & 1 & 7 & $x$ & $\frac{x}{x}$ & 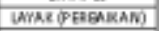 \\
\hline & HQLTE SMP 6 & $\frac{1}{2}$ & 1 & 2 & 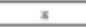 & $\gamma$ & 2 & 1 & $x$ & 2 & $\checkmark$ & $\mathrm{x}$ & 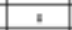 & 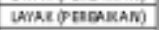 \\
\hline 27 & HQLTTLMNA & $\therefore$ & $x$ & $x$ & $x$ & 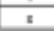 & $\frac{z}{2}$ & 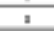 & $x$ & 2 & $x$ & 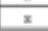 & $=$ & DEOWGWN IIMLAU \\
\hline
\end{tabular}

Berdasarkan hasil tabulasi evaluasi halte di Kota Tegal didapatkan data bahwa pada fasilitas utama halte diketahui bahwa halte yang mempunyai identitas halte sebanyak 25 buah dan sisanya 2 tidak, tidak ada halte yang mempunyai nomor halte, hanya 9 halte yangg mempunyai rambu petunjuk dan 18 tidak, hanya 9 halte yang mempunyai lampu penerangan dan sisanya 18 tidak memiliki lampu, 26 halte memiliki tempat duduk dan 1 halte MAN tidak memiliki karena halte rusak, halte yang memiliki petunjuk trayek berjumlah 8 sedangkan yang tidak memiliki berjumlah 19. Sedangkan untuk fasilitas tambahan tidak ada halte yang mempunyai fasilitas telpon umum, 13 halte mempunyai tempat sampah dan 14 halte tidak ada tempat sampah, 14 halte berpagar dan sisanya 13 tidak, 21 halte mempunyai papan pengumuman dan 6 halte tidak mempunyai, semua halte tidak memiliki layanan free wifi, dan hanya 1 halte yang mempunyai fasilitas tambahan lainnya yaitu halte pegadaian dengan tambahan peta Kota Tegal.

\section{Persepsi Masyarakat}

Untuk memastikan suatu kebijakan tepat sasaran maka perlu dilakukan kajian persepsi masyarakat berkonsep bottom up dari aspirasi masyarakat agar transportasi dapat menjadi solusi dalam mengatasi kemacetan dan mampu mengurangi ketergantungan masyarakat terhadap penggunaan kendaraan pribadi. Tujuannya adalah untuk mengetahui persepsi masyarakat serta melihat akseptasi publik terhadap kebijakan transportasi di Kota Tegal.

Data persepsi masyarakat Kota Tegal seperti di tunjukkan pada beberapa Diagram berikut.

a. Jumlah Anggota Keluarga di Rumah

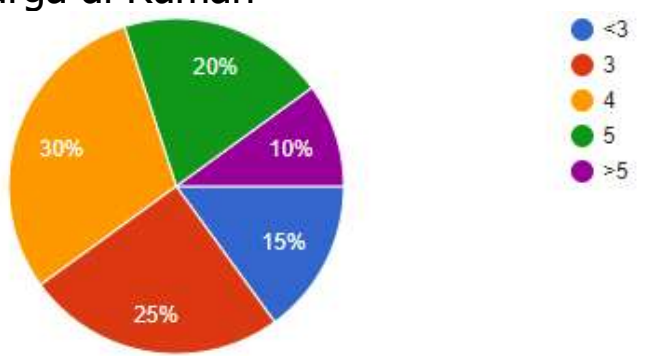

Gambar 3. Jumlah Anggota Keluarga 
Berdasarkan hasil survei di Kota Tegal didapatkan data bahwa 30\% setiap rumah di Kota Tegal mempunyai anggota keluarga sebanyak 4 orang, 25\% sebanyak 3 orang, $20 \%$ sebanyak 5 orang, 15\% kurang dari 3 orang, dan 10\% lebih dari 5 orang anggota keluarga.

b. Tingkat Pendapatan Pribadi (Jika Sudah Bekerja), Pendapatan Orang Tua (Jika Belum Bekerja)
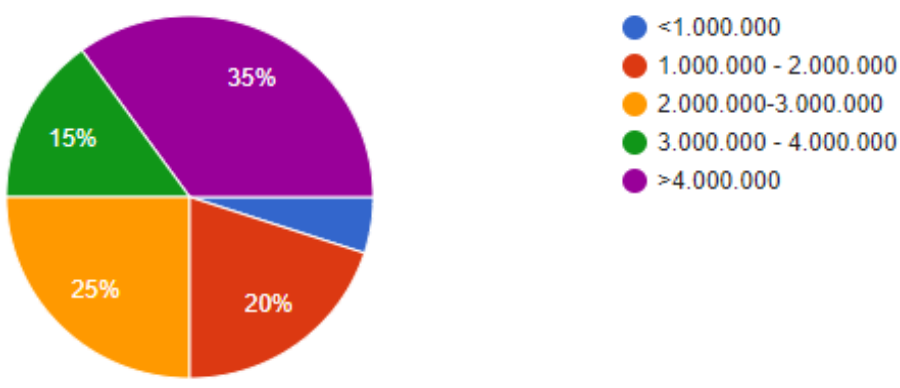

Gambar 4. Tingkat Pendapatan

Berdasarkan hasil survei, didapatkan tingkat pendapatan masyarakat yaitu 35\% > 4 juta rupiah, $25 \%$ 2juta -3 jura rupiah, $20 \%$ sebesar 1 juta -2 juta rupiah, dan $15 \%$ berkisar antara 3 juta -4 juta.

c. Lokasi Pergerakan
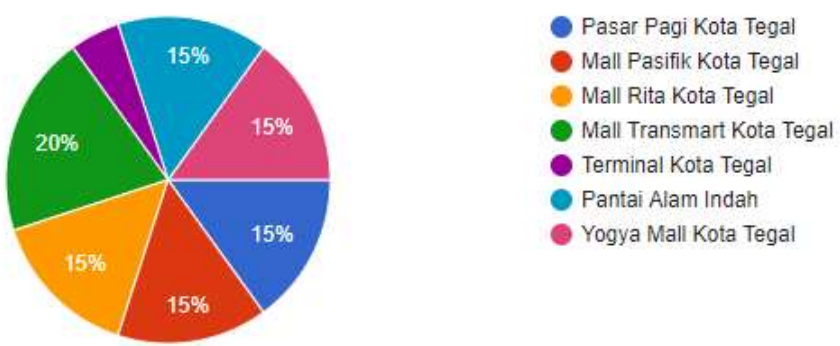

Gambar 5. Lokasi Pergerakan

Berdasarkan hasil survei di atas dapat disimpulkan bahwa pola pergerakan sebagian masyarakat Kota Tegal adalah pada pusat perdagangan, pusat bisnis, objek wisata, dan pusat pelayanan.

d. Maksud Perjalanan

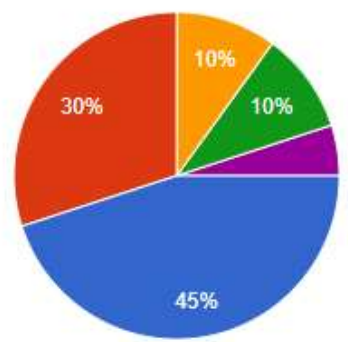

- Jalan-Jalan/Rekreasi

Belanja

Nonton

- Bekerja

- Makan dan menemani anak bermain

Gambar 6. Maksud Perjalanan

Berdasarkan hasil survei di atas dapat disimpulkan bahwa maksud perjalanan masyarakat sebagian besar adalah untuk jalan-jalan/rekreasi dan berbelanja. 
e. Moda Transportasi Saat Melakukan Perjalanan
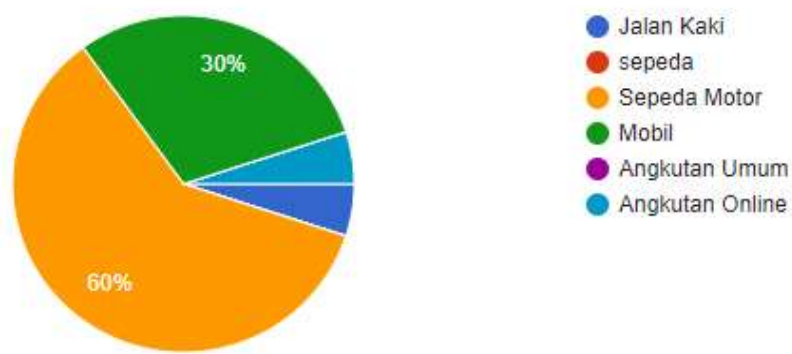

Gambar 7. Moda Transportasi

Berdasarkan hasil survei di Kota Tegal didapatkan data bahwa sebagian besar moda yang digunakan dalam melakukan perjalanan adalah sepeda motor dan mobil. Penggunaan angkutan umum sangat minim sekali.

\section{f. Alasan Penggunaan Moda Transportasi}

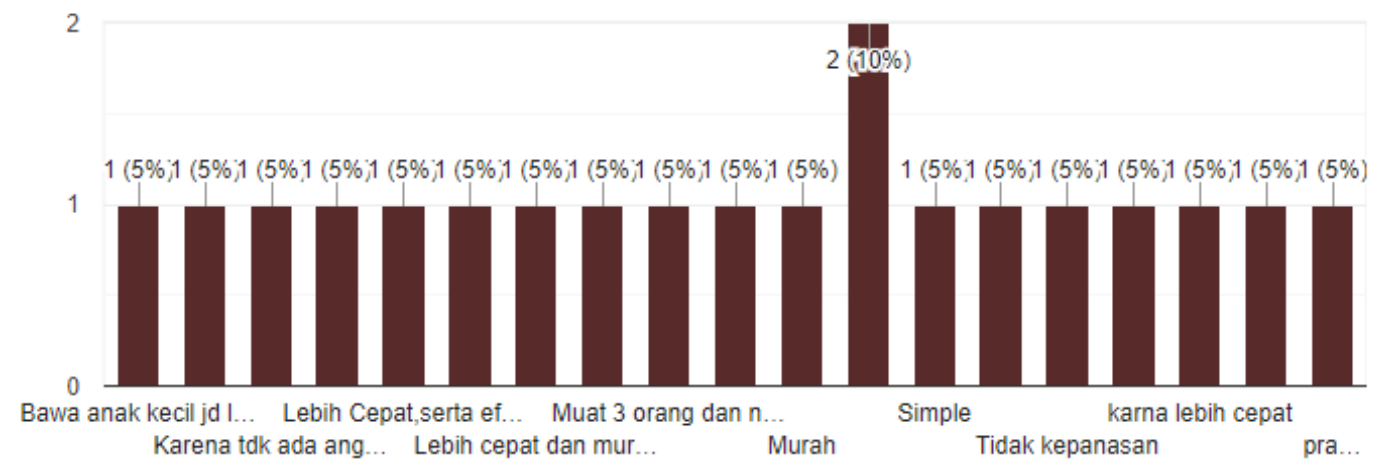

Gambar 8. Alasan Penggunaan Moda

Berdasarkan hasil survei di atas dapat disimpulkan bahwa masyarakat cenderung menggunakan moda transportasi sepeda motor dengan alasan sangat terjangkau atau murah.

\section{g. Penggunaan Halte}

Survei ini memberikan pertanyaan terkait dengan persepsi masyarakat apabila menggunakan angkutan umum apakah akan menunggu di Halte
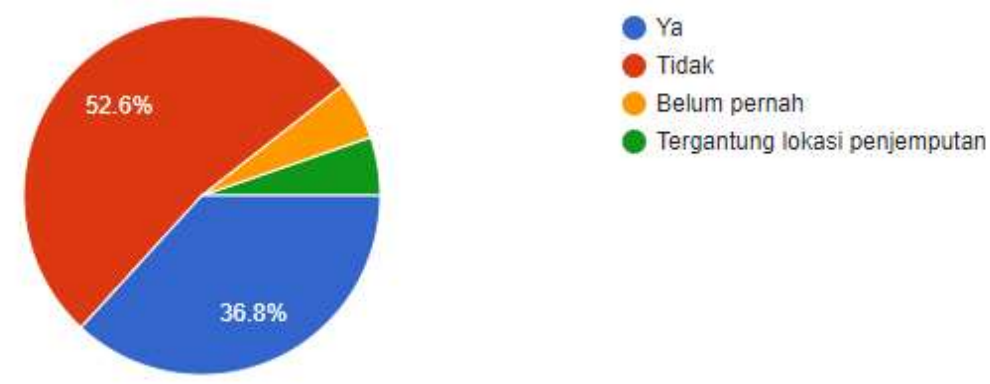

Gambar 9. Penggunaan Halte dan Terminal

Berdasarkan hasil survei di atas dapat disimpulkan bahwa masyarakat belum familiar dengan halte terbukti dengan 52,6\% menjawab tidak, dan 36,8\% menjawab Ya. 
h. Angkutan Umum yang Nyaman dan Aman

Survei ini memberikan pertanyaan terkait dengan persepsi masyarakat terkait angkutan umum yang sudah ada apakah sudah terasa nyaman dan aman.

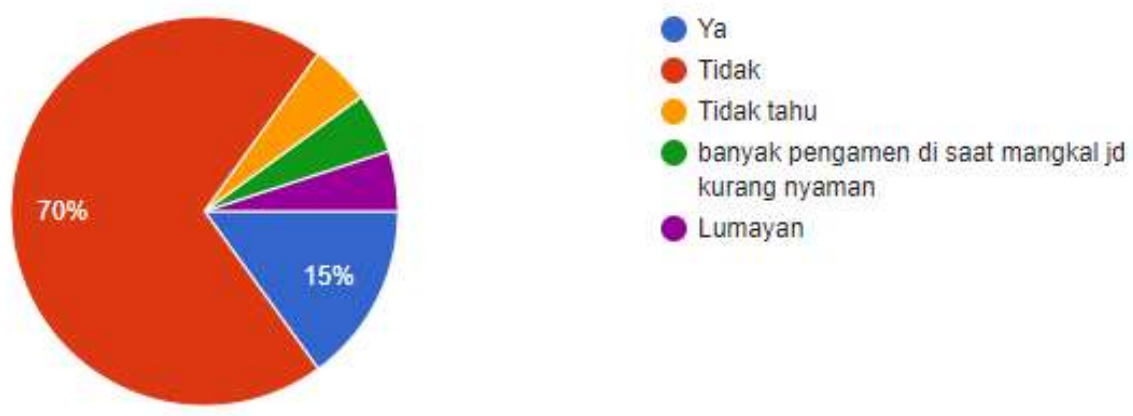

Gambar 10. Angkutan Umum Nyaman dan Aman

Berdasarkan hasil survei di atas dapat disimpulkan bahwa sebagian besar masyarakat menyatakan bahwa Angkutan umum di Kota Tegal tidak nyaman dan aman.

i. Alasan Angkutan Umum Tidak Nyaman dan Aman

Survei ini memberikan pertanyaan terkait dengan persepsi masyarakat terkait alasan apa yang mendasari masyarakat menyatakan angkiutan umum tidak nyaman dan aman.
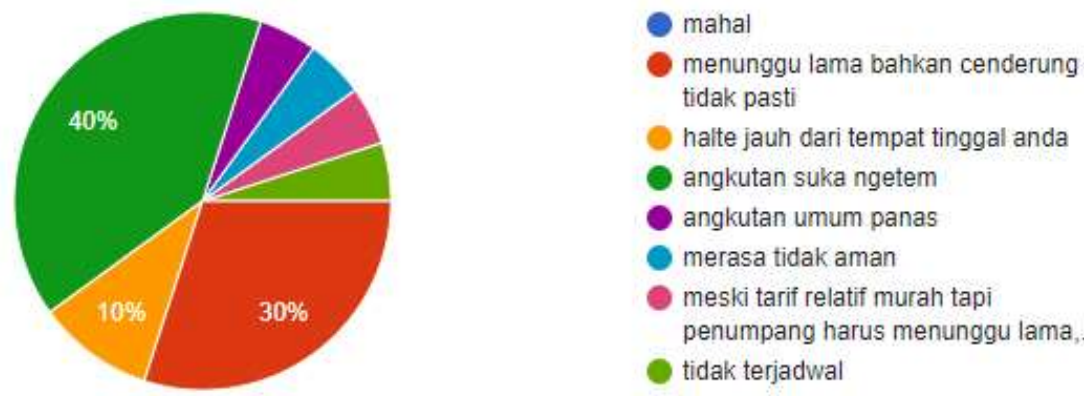

Gambar 11. Alasan Angkutan Umum Tidak Nyaman dan Aman

Berdasarkan hasil survei di atas dapat disimpulkan bahwa sebagian besar masyarakat menyatakan bahwa Angkutan umum di Kota Tegal tidak nyaman dan aman karena suka ngetem, menunggu lama dan cenderung tidak pasti, serta halte jauh dari tempat tinggal.

j. Kebutuhan Halte

Survei ini memberikan pertanyaan terkait dengan persepsi masyarakat terkait apakah masyarakat membutuhkan halte untuk menunggu angkutan umum.

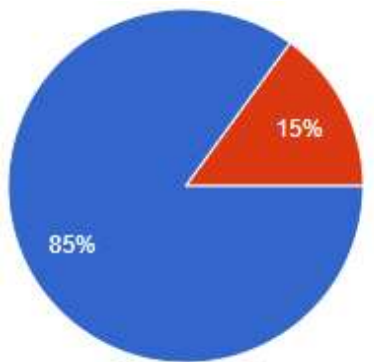

- Ya

Tidak

Gambar 12. Kebutuhan Halte 
Berdasarkan hasil survei di atas dapat disimpulkan bahwa sebagian besar masyarakat menyatakan bahwa $85 \%$ masyarakat membutuhkan halte untuk menunggu angkutan umum.

k. Kriteria Halte yang ideal

Survei ini memberikan pertanyaan terkait dengan persepsi masyarakat terkait pertanyaan sebelumnya tentang halte yang dibutuhkan masyarakat. Berdasarkan hasil survei masyarakat menginginkan halte dengan kriteria:

a. Nyaman, aman, dan nyaman;

b. Memiliki akses listrik dan internet;

c. Tersedia jadwal dan rute trayek;

d. Tidak membosankan

Dari data presepsi masyarakat dapat ditarik kesimpulan bahwa masih ada potensi besar dalam penggunaan halte, dalam hal ini orang akan menggunakan halte untuk menunggu angkutan umum jika ada perbaikan juga dari pelayanan angkutan umum diantara nya perbaikan pelayanan dapa rute angkutan umum untuk tidak menunggu penumpang terlalu lama tampa kepastian atau ngetem, sedangkan halte yang di kehendaki oleh masyarakat yaitu nyaman, aman, memiliki akses listrik dan internat, tersedia jadwal dan rute trayek serta tidak membosankan.

\section{Potensi Kebutuhan Halte}

Penentuan lokasi dan jumlah halte baru memiliki peran yang penting dalam penggunaan moda angkutan umum di Kota Tegal. Pembangunan halte yang tidak optimal akan menyebabkan permasalahan transportasi semakin meningkat, karena banyak masyarakat yang awalnya ingin menggunakan moda ini namun menjadi malas untuk memanfaatkan moda ini. Hal ini disebabkan terdapat kesulitan disaat akan menggunakanan fasilitas yang tersedia. Banyak penumpang yang tidak menggunakan fasilitas halte sebagai tempat naik dan turun dari angkutan umum dikarenakan jarak yang harus ditempuh menuju ke halte terlalu jauh. Oleh sebab itu, penentuan lokasi dan jumlah halte harus optimal. Dengan ditentukannya lokasi dan jumlah halte yang optimal maka dapat memberi kemudahan bagi penumpang yang ingin menggunakan angkutan umum. Jika jumlah halte yang dibangun semakin banyak maka semakin besar kemudahan yang diperoleh penumpang. Namun, pembangunan halte juga harus efektif. Penentuan lokasi baru halte juga harusnya mempertimbangkan jaringan trayek angkutan umum yang ideal.

Penentuan lokasi dan jumlah halte paling mudah menggunakan pendekatan lokasi yang memiliki potensi membangkitkan penumpang yang cukup tinggi dan pusat pelayanan publik dan jaringan angkutan umum dan Berdasarkan hasil kuisioner persepsi masyarakat bahwa maksud perjalanan kota tegal $45 \%$ yaitu rekreasi dan $30 \%$ bebelanja, Berdasarkan hal tersebut berikut potensi-potensi halte yang bisa di bangun di Kota Tegal. 


\section{Tabel 2. Potensi-Potensi Halte Yang Bisa Di Bangun Di Kota Tegal}

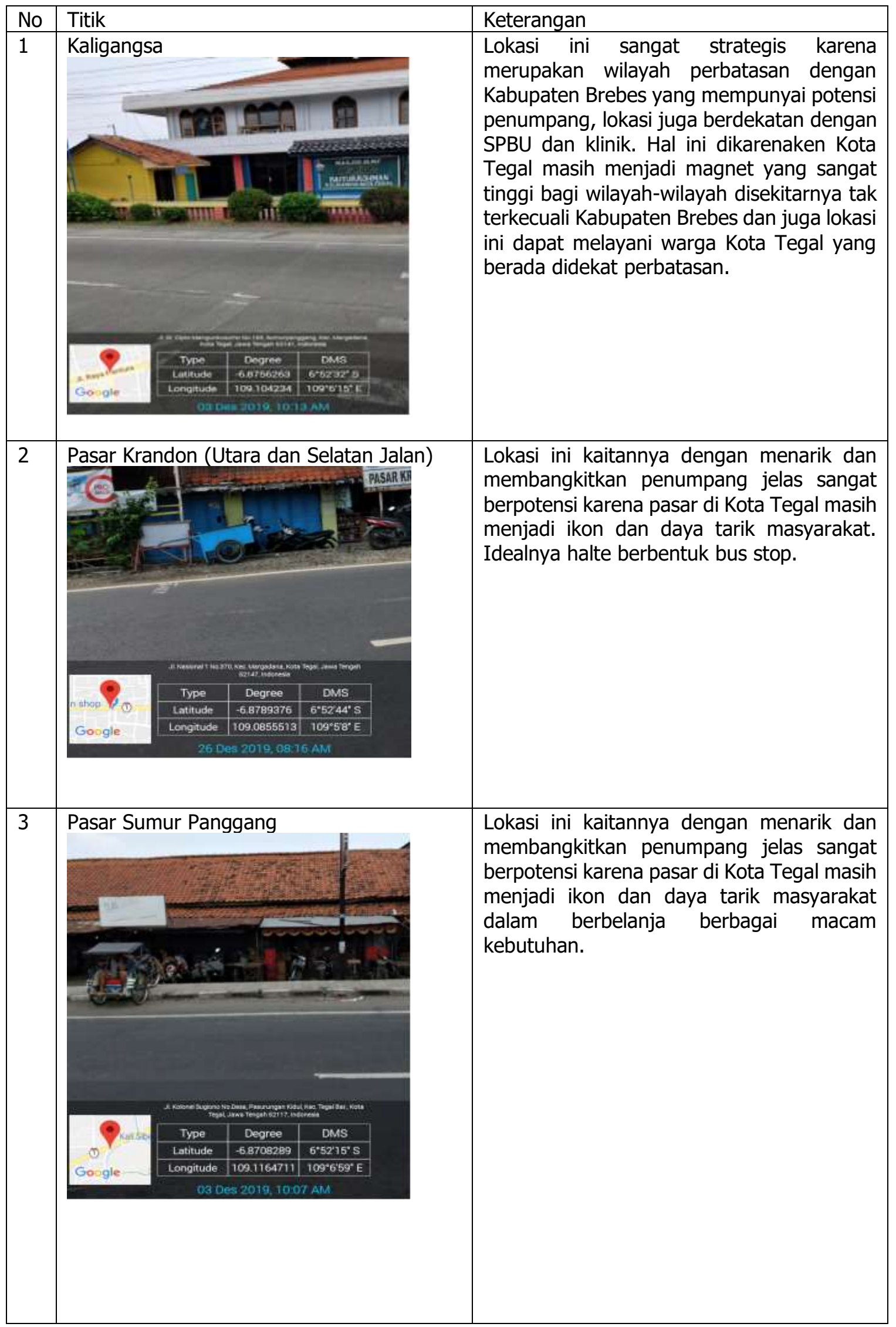




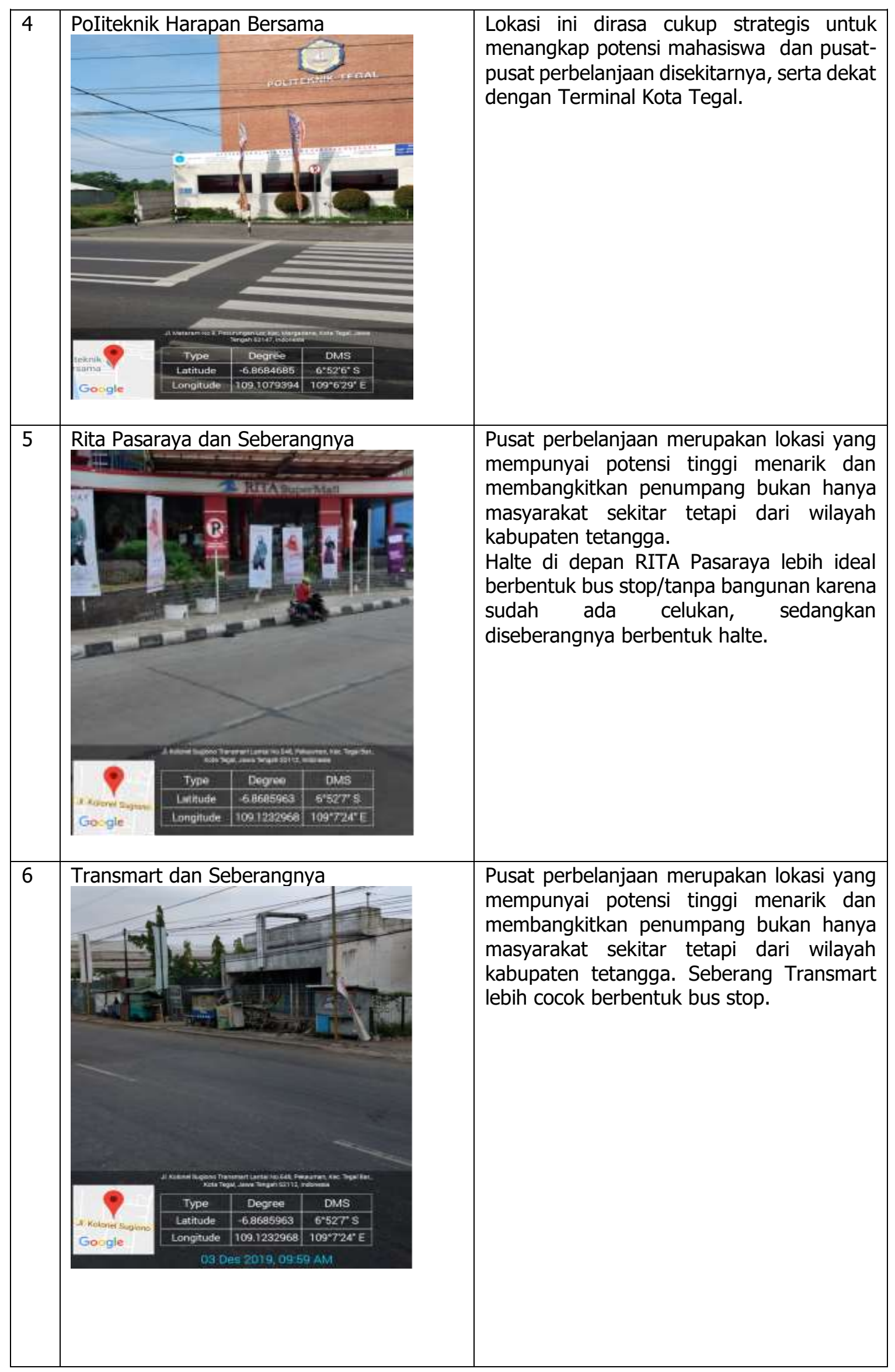




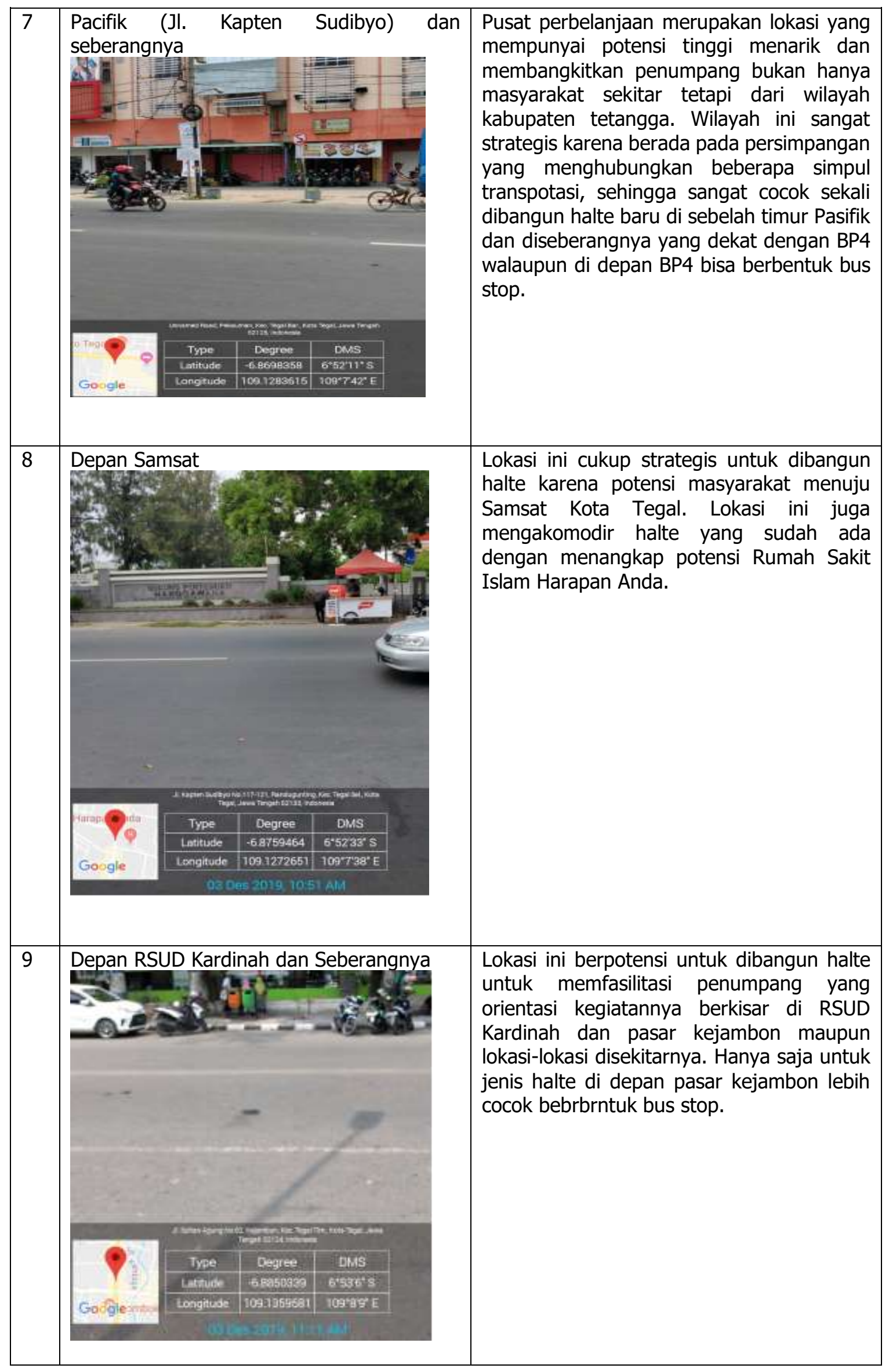




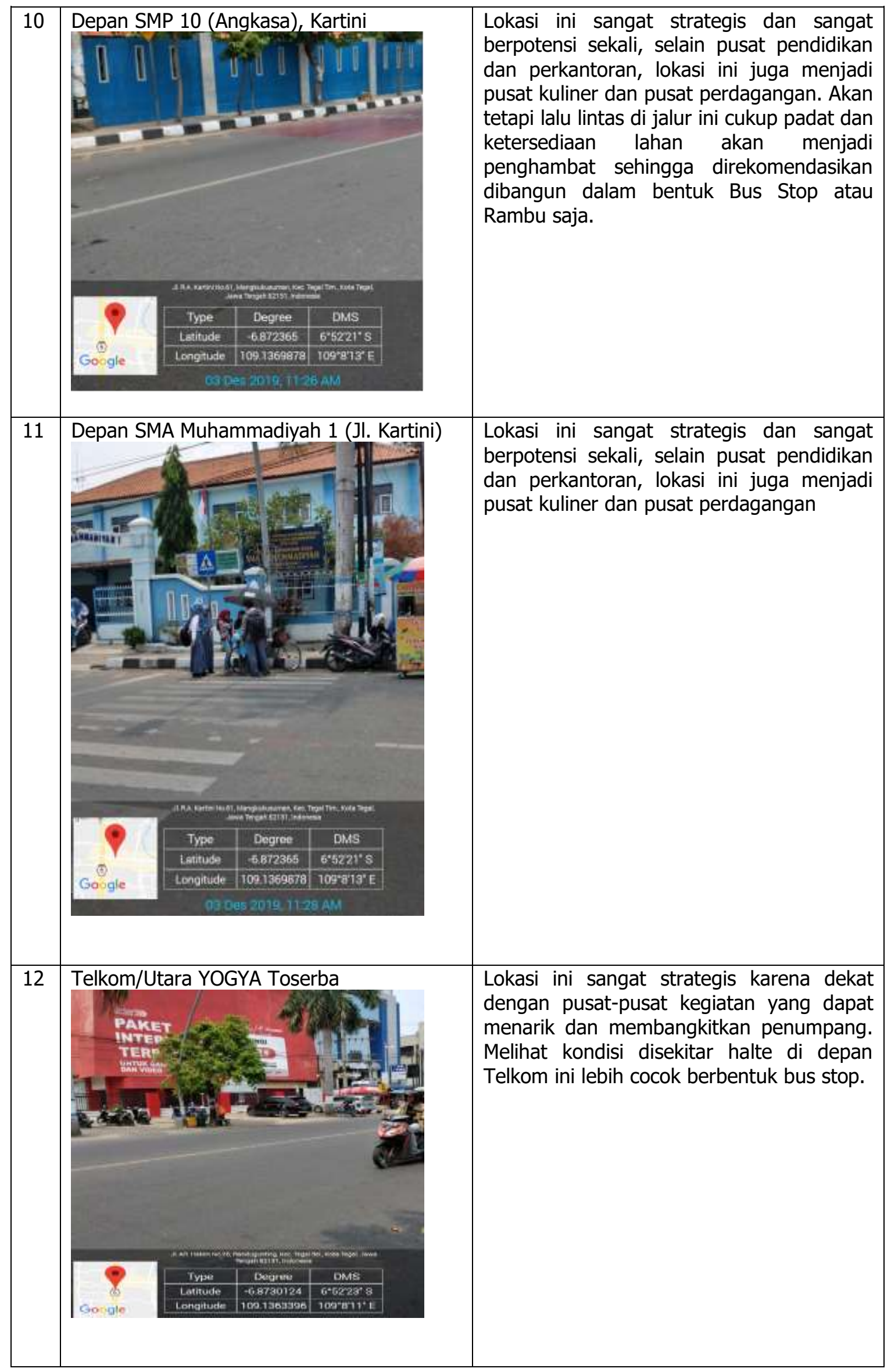




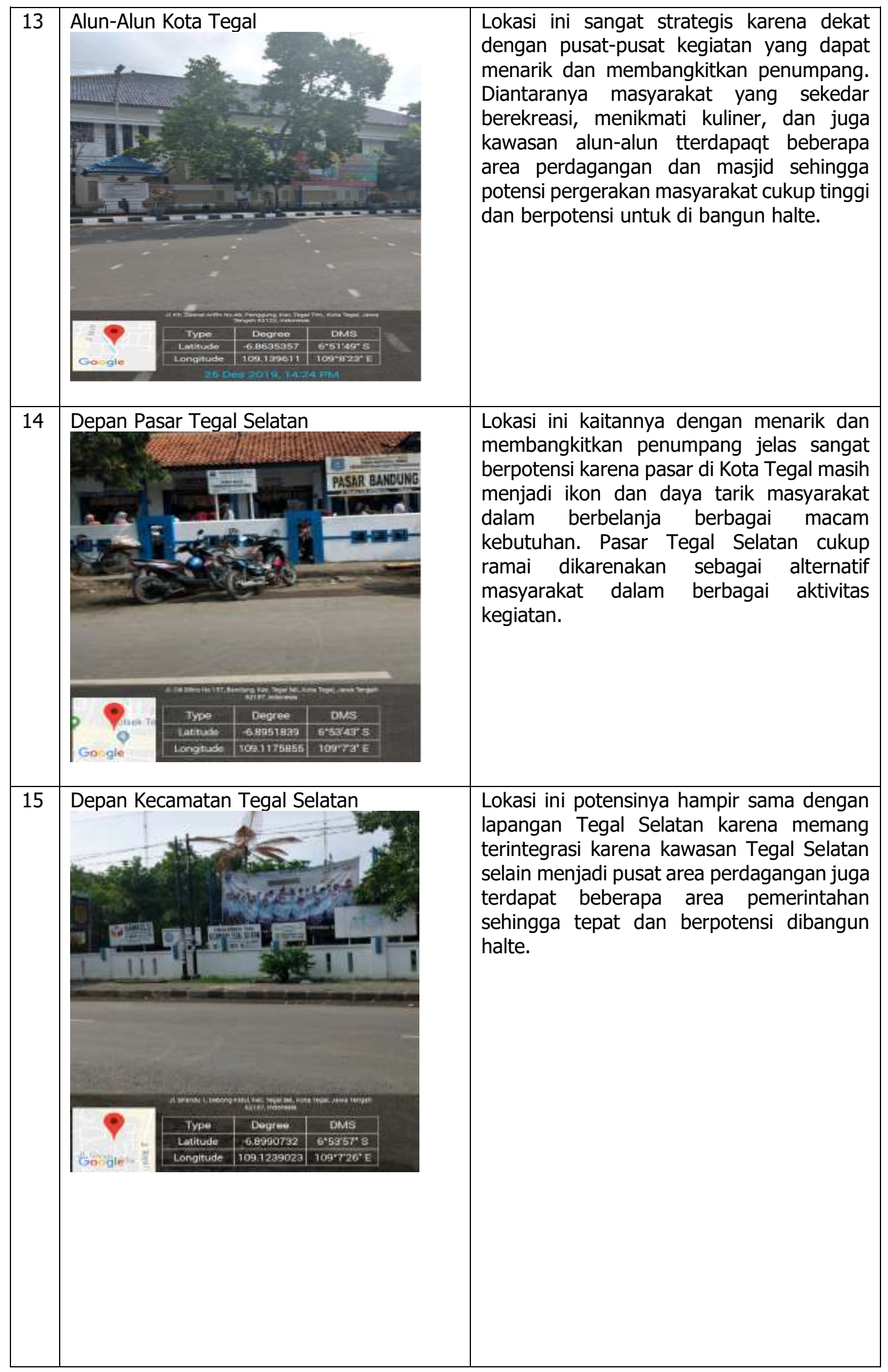




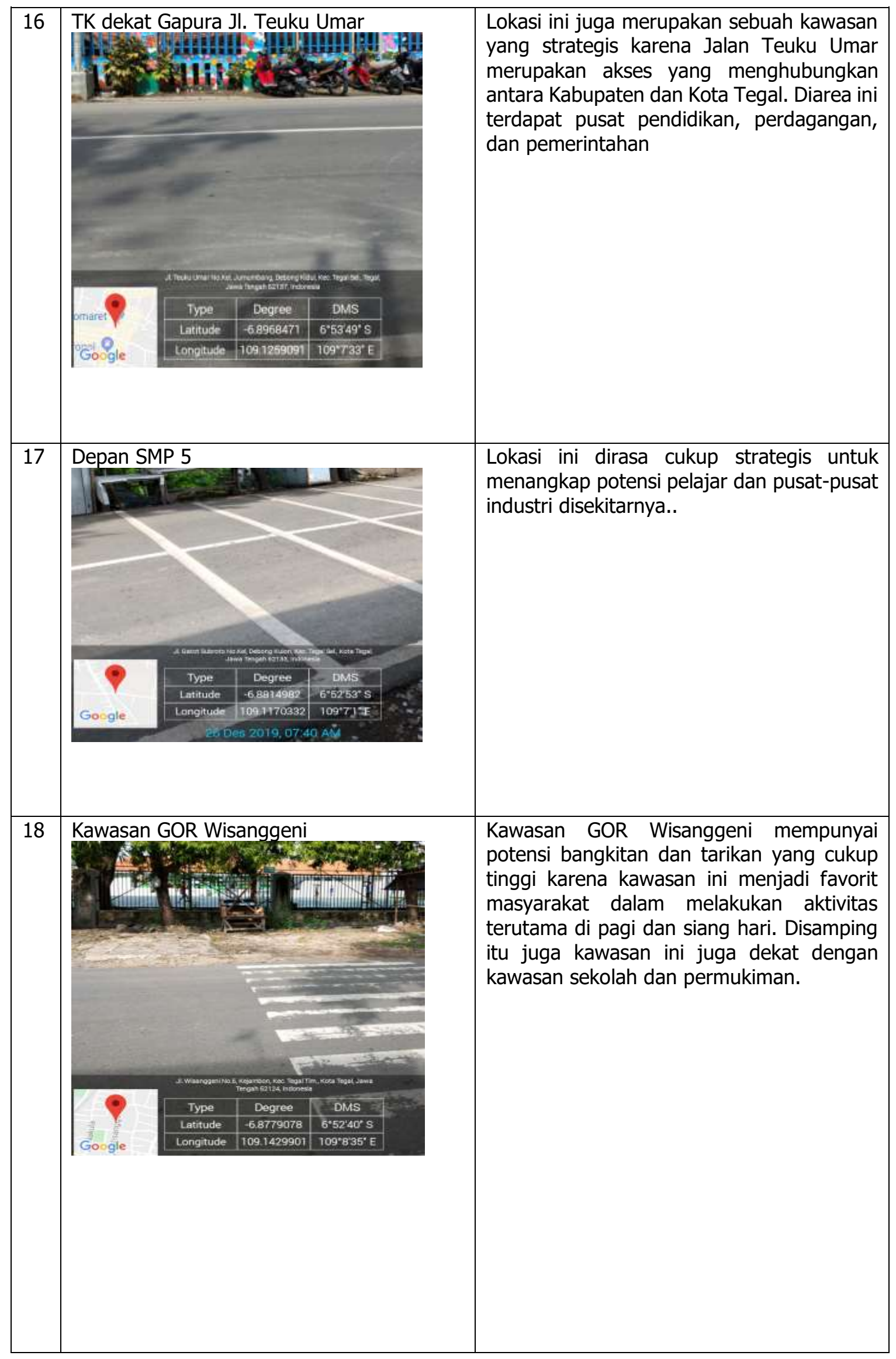




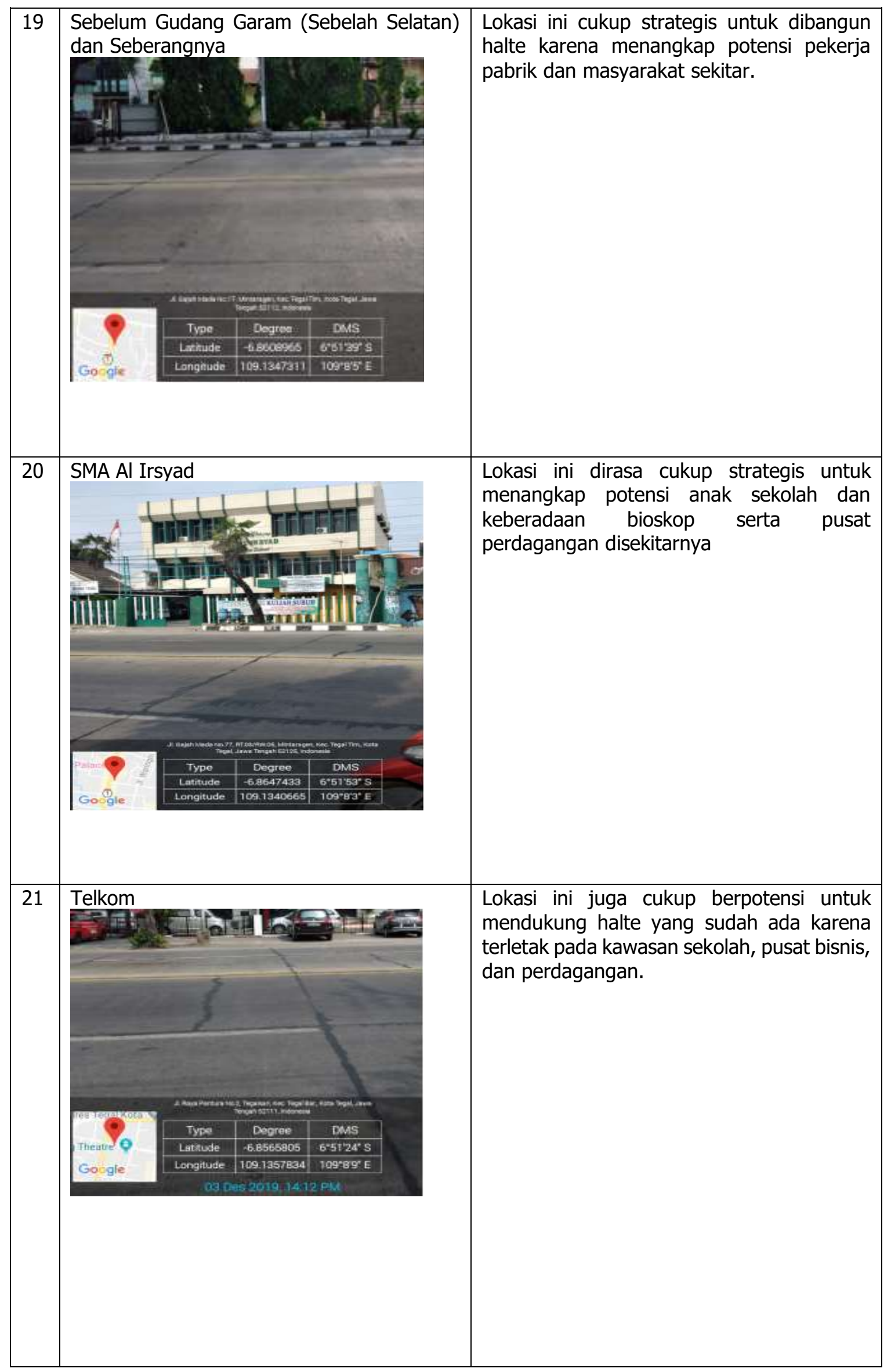




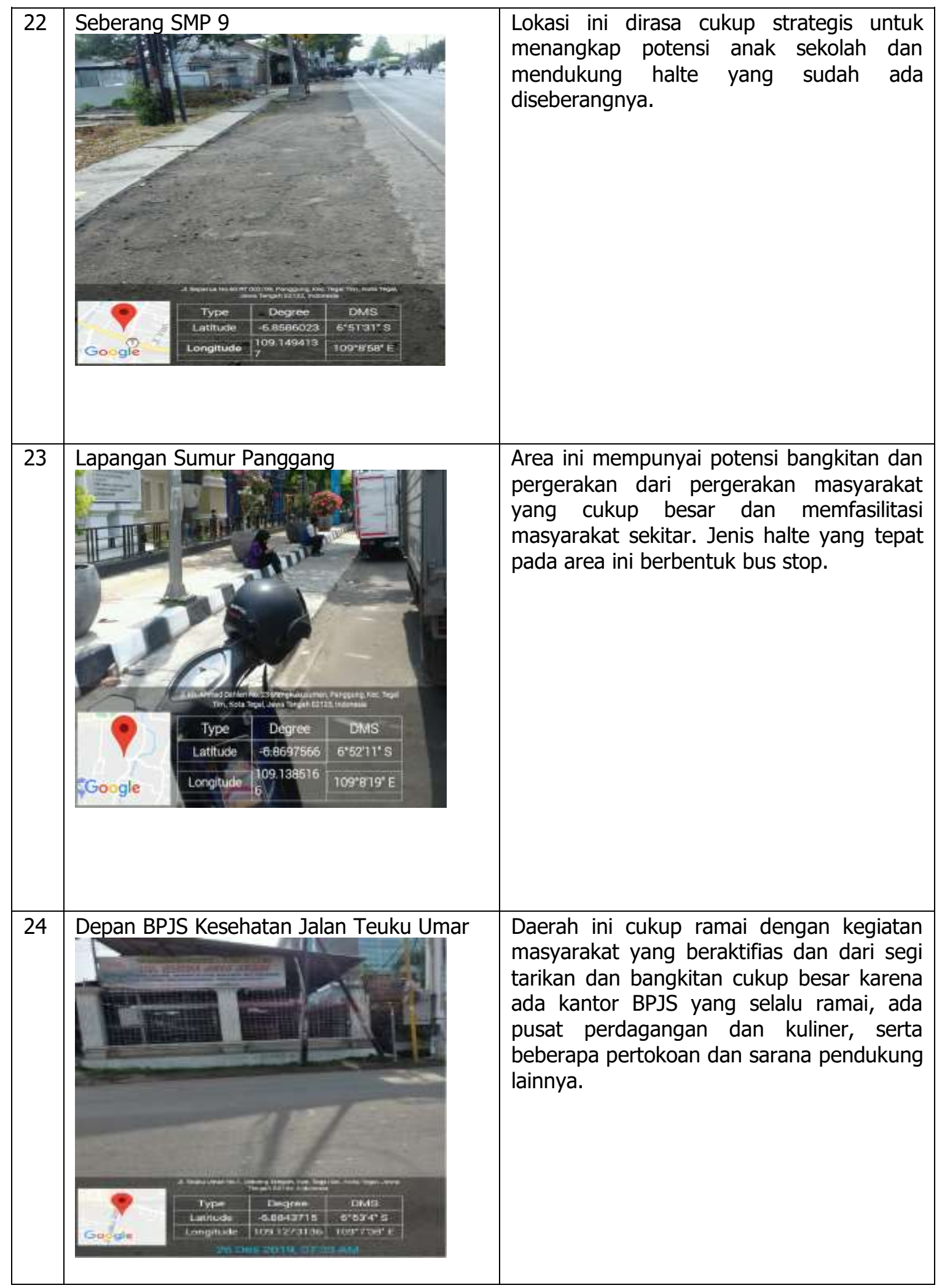

Kondisi halte eksisting dan proyeksi halte baru yang memungkinkan akan dibangun untuk memperbaiki sistem transportasi dan pelayanan kepada masyarakat ditunjukkan seperti pada Gambar 1.2 berikut : 


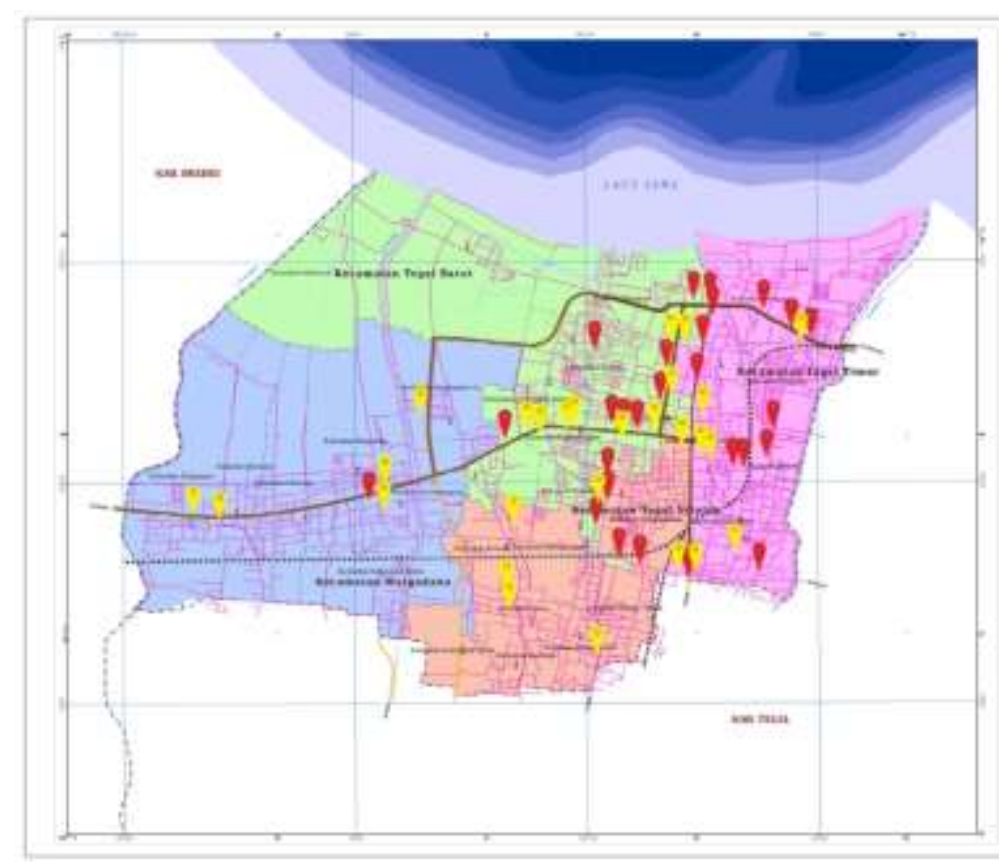

Gambar 13. Letak Halte Eksisting dan Potensi

\section{Desain Halte}

Pada penelitian ini penulis merekomendasikan desain halte yang telah di teliti oleh peneliti sebelumnya dimana perancangan halte harus mengedepankan human centered desaign bukan hanya sekedar menyelesaikan pembangunan, (Hasibuan, 2018)

\section{PENUTUP}

Kebutuahn penyediaan halte mengedepankan pelayanan dari angkutan umum itu sendiri dan kebutuhan dari masyarakat baik dari tata letaknya maupun desain halte agar tercapai pelayanan yang optimal serta dapat menguruangi penggunaan angkutan pribadi dan meningkatkan penggunaan angkutan umum.

Dari 27 halte eksisting terdapat 4 unit halte harus dibongkar/pindah, sedangkan 23 unit masih dapat melayani pelayanan angkutan. Berdasarkan hasil analisis kebutuhan diperoleh kebutuhan halte tambahan sebanyak 24 unit.

\section{DAFTAR PUSTAKA}

Aminah, S. (2018). Transportasi Publik dan Aksesibilitas Masyarakat Perkotaan. jurnal teknik sipil UBL, 9.

Creswell, J W. (2008). Research Design: Qualitative and Quantitative Approach. California: Sage Publication.

Farizi, A. S. al dan T. T. (2016). Persepsi Pengguna Transjakarta terhadap Aspek Amenity pada Fasilitas Pejalan Kaki di Halte Dukuh Atas dengan Pendekatan Teori Perilaku Terencana. Jurnal Transportasi, 16(3), pp. 183-192. 
Groat, L. and Wang, D.( 2002). Architectural Research Methods, John Wiley and Sons. Inc. Canada

Hasibuan, C. F. dan sutrisno. (2018). Rancangan Shelter / Halte Brt Mebidang ( Bus Rapid Transit Medan-Binjai-Deliserdang ) Untuk Mempermudah Aksesbilitas Masyarakat Kebutuhan. Spektrum industri, 16(27), pp. 111-225.

Kementrian Pekerjaan Umum dan Perumahan Rakyat (2018). Perencanaan teknis fasilitas pejalan kaki.

Perhubungan, D. J. P. D. D. (1996). Pedoman Teknis Perekayasanaan Tempat Perhentian Kendaraan Penumpang Umum. 